\title{
Respiratory activity in sediments of three mountain lakes in the Julian Alps and in subalpine Lake Bled (Slovenia): effects of altitude and anthropic influence
}

\author{
Gregor Muri*, Tatjana Simčič \\ National Institute of Biology, Večna pot 111, 1000 Ljubljana, Slovenia
}

\begin{abstract}
Respiratory activity in sediments was studied in 3 Slovenian mountain lakes and 1 subalpine lake. Electron transport system (ETS) activity was measured in the sediments to assess the potential mineralisation of organic matter $(\mathrm{OM})$, while oxygen consumption rate $(R)$, induced under laboratory conditions, was used to assess the actual mineralisation of OM in these sediments. The lakes are situated at different altitudes, with different water temperatures. They also have different trophic status. It was found that higher lake water temperatures and more productive lakes, having higher contents of labile autochthonous OM, caused higher microbial respiratory activity, reflected in higher ETS activities and $R$. Subsurface peak values of ETS activity and $R$ were observed in the mountain lakes, most probably indicating slower degradation of $\mathrm{OM}_{i}$ in particular, the more refractory terrestrial $\mathrm{OM}$, and the presence of anaerobic microorganisms. In the case of the lowland eutrophic Lake Bled, no such distribution was observed. In this lake, OM is effectively degraded in the water column and surface sediments due to high lake water temperatures and high content of autochthonous OM. A high correlation between ETS activity and $R$ was observed in all the sediments, while correlations between ETS activity and organic carbon (OC) concentration, and between $R$ and $\mathrm{OC}$ concentration were lower.
\end{abstract}

KEY WORDS: ETS activity $\cdot$ Oxygen consumption rate $\cdot$ Mineralisation $\cdot$ Organic matter $\cdot$ Alps

\section{INTRODUCTION}

Most organic matter (OM) produced in, or supplied to, aquatic systems is eventually mineralised in either the water column or in surface sediments, where early diagenesis occurs (Relexans 1996). In shallow water systems, most mineralisation takes place in sediments through benthic metabolism, rather than in the water column (Vosjan \& Olanczuk-Neyman 1977). Exceptions are shallow turbulent lakes where up to $60 \%$ of OM mineralises in the water column. Determination of the rate of benthic metabolism is important in studies of nutrient diagenesis in sediments and in assessing the role of benthos in carbon cycling in ecosystems (Suess 1980). The total oxygen consumption rate is a common measure for estimating the benthic metabolic rate.
The oxygen consumption rate $(R)$ is determined by the momentary metabolic activity of organisms. Since oxygen consumption measurement is time-consuming and, in some cases (in deep-sea sediments), costly and hard to achieve, other methods have been developed. As in most cases the electron transport system (ETS) bridges the oxidation of $\mathrm{OM}$ and molecular $\mathrm{O}_{2}$, benthic metabolism can be estimated by measuring ETS activity. The latter, the system of enzymes and cytochromes involved in respiratory energy production, has often been used to estimate $R$ in sediments (Christensen 1983). It is measured in vitro, and the advantages of the method are that the measurement is highly sensitive and relatively easy (Packard \& Williams 1981).

Various factors affect metabolic activity, such as temperature, hydrostatic pressure, the quality and 
quantity of OM, and the nature of the dominant electron acceptors. Thus, ETS activity is dependent on these parameters, whose effects have been examined closely (Christensen 1983, Trevors 1984, Broberg 1985, G.-Tóth et al. 1994, Relexans 1996). The ETS activity method has been widely applied to plankton samples (e.g. Kenner \& Ahmed 1975, Packard 1985, del Giorgio 1992), less frequently to marine sediments (e.g. Vosjan \& Olanczuk-Neyman 1977, Packard \& Williams 1981, Christensen 1983, Relexans 1996), and rarely to freshwater sediments (e.g. Broberg 1985, G.-Tóth 1992, G.-Tóth et al. 1994, Simčič \& Brancelj 2002).

High-altitude mountain lakes are generally shallow, have a modest-sized watershed and rapid flushing rates, and are sensitive and vulnerable ecosystems. Thus, they should be valuable indicators of environmental change and be able to provide information on the consequences of human impact on pristine environments. Mountain lakes have long ice-cover periods and low temperatures. Oxygen content is reduced during the former, while degradation of OM in the sediments is depleted due to low bottom water temperatures (Thies et al. 1999). In combination with short sinking times, mineralisation of $\mathrm{OM}$ in the water column as well as in the sediments of mountain lakes is slow.

In this study, ETS activity and $R$ were determined in the sediments of 3 Slovenian mountain lakes and 1 subalpine lake. Their vertical profiles were measured at a standard temperature of $20^{\circ} \mathrm{C}$. ETS activity is an indicator of the potential mineralisation of OM, while $R$ is an 'apparent' indicator of actual mineralisation of

Table 1. Topographic characteristics of sampling sites at each of the 4 lakes, the physical and chemical properties in the water column, and geochemical properties of the sediments. $T$ : temperature; $\mathrm{O}_{2}$ : dissolved oxygen; TP: total phosphorus; TL: total terrestrial lipids; AL: total autochthonous lipids; na: not analysed (data from Muri 2003, Muri \& Brancelj 2003, Brancelj 2002, Simčič 2000)

\begin{tabular}{|c|c|c|c|c|}
\hline Characteristic & Kriško Sup. & Ledvica & Planina & Bled \\
\hline Latitude (N) & $46^{\circ} 24^{\prime} 32^{\prime \prime}$ & $46^{\circ} 20^{\prime} 25^{\prime \prime}$ & $46^{\circ} 18^{\prime} 40^{\prime \prime}$ & $46^{\circ} 22^{\prime} 30^{\prime \prime}$ \\
\hline Longitude (E) & $13^{\circ} 48^{\prime} 34^{\prime \prime}$ & $13^{\circ} 47^{\prime} 12^{\prime \prime}$ & $13^{\circ} 49^{\prime} 56^{\prime \prime}$ & $14^{\circ} 07^{\prime} 30^{\prime \prime}$ \\
\hline Altitude (m) & 2150 & 1830 & 1430 & 475 \\
\hline Surface area (ha) & 0.66 & 2.19 & 1.56 & 147 \\
\hline Max. depth (m) & 9 & 15 & 11 & 30 \\
\hline \multicolumn{5}{|l|}{ Water column } \\
\hline$T\left({ }^{\circ} \mathrm{C}\right)(\text { surface } / \text { bottom })^{\mathrm{a}}$ & $15.0 / 4.5$ & $14.9 / 4.8$ & $19.5 / 6.5$ & $27.3 / 8.8$ \\
\hline Ice cover (months) & 8.5 & 6.5 & 5.5 & 2 \\
\hline $\mathrm{O}_{2}\left(\mathrm{mg} \mathrm{l}^{-1}\right)$ (hypolimnion) $)^{\mathrm{b}}$ & 6.3 & 9.2 & 0.5 & 0.6 \\
\hline $\mathrm{TP}\left(\mu \mathrm{g} \mathrm{P} \mathrm{l}^{-1}\right)$ (hypolimnion) & 42 & 19 & 264 & 101 \\
\hline \multicolumn{5}{|l|}{ Surface sediment } \\
\hline $\mathrm{TL}\left(\mu \mathrm{g} \mathrm{g} \mathrm{g}^{-1} \mathrm{OC}\right)$ & na & na & 8550 & 4550 \\
\hline $\mathrm{AL}\left(\mu \mathrm{g} \mathrm{g}^{-1} \mathrm{OC}\right)$ & na & na & 4350 & 5300 \\
\hline $\begin{array}{l}{ }^{\mathrm{a}} \text { Maximum values } \\
{ }^{\mathrm{b}} \text { Minimum values }\end{array}$ & & & & \\
\hline
\end{tabular}

OM, since the latter was induced and measured under laboratory conditions. In parallel, organic carbon (OC) and total nitrogen (TN) concentrations were determined in the sediments, to give $\mathrm{C} / \mathrm{N}$ ratios. Finally, the main objectives of the study were to assess the effects of lake water temperature and of the lability of OM on the 2 parameters, and to compare the difference between mineralisation of $\mathrm{OM}$ in the mountain and lowland lakes. At present, there are very few published data on the ETS activity and $R$ in mountain lakes, although these lakes still retain their original environmental status and can sensitively show initial human impacts. Simčič \& Brancelj (2002) measured the surface sediment ETS activity and $R$ in several Slovenian mountain lakes, while G.-Tóth et al. (1995) measured the ETS activity in plankton. Thus, the present study contributes to a better understanding of OM degradation in alpine/subalpine ecosystems.

\section{MATERIALS AND METHODS}

Sampling site. We selected 3 remote mountain lakes, Lake Kriško Sup., Lake Ledvica and Lake Planina, and the subalpine Lake Bled, all situated in the northwestern part of Slovenia, as study sites. Their topographical characteristics and physical and chemical properties are summarised in Table 1 . The mountain lakes are relatively small ( 0.7 to $2.2 \mathrm{ha}$ ), shallow (9 to $15 \mathrm{~m}$ ) and of glacial origin. They are all located in the Triglav National Park, in the protected area of the Julian Alps. Lake Kriško Sup. and Lake Ledvica are above the tree line and are relatively pristine. Their water columns are saturated with oxygen throughout the year and the lakes are still oligo/mesotrophic (Muri \& Brancelj 2003). In contrast, Lake Planina is located below the tree line. There is also a mountain hut situated just above the lake, while a pasture, surrounding the lake, is used for grazing cattle. Thus, the anthropogenic impact on Lake Planina is stronger than on the other mountain lakes, and is reflected in higher concentrations of OM and suboxic/anoxic conditions in the deeper layers of the water column. The lake is eutrophic (Muri \& Brancelj 2003).

Lake Bled is a eutrophic subalpine lake of glacial origin, and is located in an urban area. Morphologically, it can be divided into 2 basins separated by an island. The western basin is deeper, reaching $30 \mathrm{~m}$, while the eastern basin has a maximum depth of 
$24 \mathrm{~m}$. The condition of the lake is poor. Suboxic/anoxic conditions are present in the deeper layers of the water column and algal blooms are occasionally observed (Simčič 2000). To promote the lake's recovery, siphon pumping of anoxic water was begun in 1982 .

Water temperature. In Lake Kriško Sup. and Lake Ledvica, water temperatures were quite low, with surface water temperatures below $15^{\circ} \mathrm{C}$, even in midsummer (Brancelj 2002). The summer temperatures of the bottom layers of the water column ranged from 4 to $7^{\circ} \mathrm{C}$. Up to $2^{\circ} \mathrm{C}$ higher temperatures were observed in Lake Ledvica than in Lake Kriško Sup. due to the former's lower altitude and approximately 2 mo shorter period of ice cover. Summer surface water temperatures rose to $20^{\circ} \mathrm{C}$ in Lake Planina, while bottom layer temperatures ranged from 5 to $7^{\circ} \mathrm{C}$ (Brancelj 2002). In winter, lake water temperatures around $4^{\circ} \mathrm{C}$ were observed in all the mountain lakes.

Surface water temperatures in Lake Bled were high, reaching $27^{\circ} \mathrm{C}$ in summer. Bottom-layer temperatures in contrast rarely dropped below $6^{\circ} \mathrm{C}$ (Simčič 2000).

Sampling. Sediments were collected in August 2000. During sampling, oxic conditions were observed in the hypolimnion of Lake Kriško Sup. and Lake Ledvica. In Lake Planina and Lake Bled, conditions in the hypolimnion were, in contrast, suboxic. Surface water temperatures were $15.5^{\circ} \mathrm{C}$ in Lake Kriško Sup., $14.6^{\circ} \mathrm{C}$ in Lake Ledvica, $17.6^{\circ} \mathrm{C}$ in Lake Planina and $22.9^{\circ} \mathrm{C}$ in Lake Bled. Bottom water temperatures ranged from 4 to $7^{\circ} \mathrm{C}$ in all the lakes. Sediment cores were taken using a modified Kajak-Brinkhurst gravity corer equipped with a $70 \times 6 \mathrm{~cm}$ diameter plexiglass tube. The cores were collected from the deepest part of the lakes, extruded in the field and cut into $1 \mathrm{~cm}$ slices. Each core was used for ETS activity, $R$, OC and TN measurements. The samples were transported to the laboratory within $24 \mathrm{~h}$ in a cold box $\left(4^{\circ} \mathrm{C}\right)$ and were analysed immediately upon arrival.

Different sedimentation rates were observed in the lakes. The lowest measured slice represented an age of approximately $25 \mathrm{yr}$ in Lake Kriško Sup., 200 yr in Lake Ledvica, $115 \mathrm{yr}$ in Lake Planina and $85 \mathrm{yr}$ in Lake Bled (for sedimentation rates see Brancelj et al. 2002, Muri et al. 2002, 2003).

Analyses. ETS activity was analysed using the method proposed by G.-Tóth (1999). Fresh sediment samples were weighed and immediately homogenised using an ultrasonic homogeniser (Cole-Parmer Instrument 4710 Series). Within $10 \mathrm{~min}$, the homogenate was incubated with the substrate solution (NADH, NADPH and Triton X100) and the reagent solution (iodonitrotetrazolium chloride, INT) for $40 \mathrm{~min}$ at a standard temperature $\left(20^{\circ} \mathrm{C}\right)$. The reaction was stopped by the addition of stopping-solution (formalin and $\mathrm{H}_{3} \mathrm{PO}_{4}$ ). Blanks (the substrate and reagent solution) were incubated and stopped as for the test samples, and homogenate was then added. Formazan production was determined spectrophotometrically (Perkin Elmer, Lambda 12) from the absorbance of the sample at $490 \mathrm{~nm}$ against the blank within $10 \mathrm{~min}$ of stopping the reaction. ETS activity was measured as the rate of tetrazolium dye reduction, which was converted to equivalent oxygen utilised $\mathrm{g}^{-1}$ dry weight (DW) in a given time interval $\left(\mu \mathrm{O}_{2} \mathrm{~g}^{-1} \mathrm{DW} \mathrm{h}^{-1}\right)$ as described by Kenner \& Ahmed (1975). The dry weight of each sediment slice was determined by drying for $24 \mathrm{~h}$ at $60^{\circ} \mathrm{C}$. A conversion factor was then obtained to recalculate the wet weight of the sediment sample to the dry weight. The buffers for homogenisation, substrate solution, reagent solution and stopping solution were prepared immediately prior to the experiments to avoid substrate decomposition and bacterial contamination. Analyses were performed in triplicate. Standard deviations of these measurements ranged from 5 to $15 \%$. Since INT can be reduced by both aerobes and anaerobes (Songster-Alpin \& Klotz 1995), the determined ETS activity was a measure of the total microbial respiratory activity.

$R$ was measured using the closed-bottle method (Lampert 1984). Bottles $(300 \mathrm{ml})$ with ground-glass stoppers were filled with filtered water from each lake, and aerated in advance for $24 \mathrm{~h}$. Air was passed through a water filter to eliminate particles and bacteria. Bottles were filled with about $1 \mathrm{~g}$ of wet sediments. For each set of bottles, 3 bottles were without sediment served as controls. All bottles were stoppered and kept in the dark at a standard temperature of $20^{\circ} \mathrm{C}$. After $70 \mathrm{~h}$, the concentration of dissolved oxygen in the experimental and control bottles was measured using a polarographic oxygen electrode (WTW, Oxi 320). Final dissolved oxygen concentrations ranged from 5.5 to $7 \mathrm{mg} \mathrm{O}_{2} \mathrm{l}^{-1}$ in the experimental bottles, and averaged $8.3 \mathrm{mg} \mathrm{O}_{2} \mathrm{l}^{-1}$ in the control bottles. The difference between the amount of oxygen in the experimental bottles and that in the control was taken as the amount of oxygen consumed by the microzoobenthos and microbial communities. Analyses were performed in triplicate. Higher standard deviations were observed than in the case of the ETS analyses, and ranged around $15 \%$.

OC content was determined after acidification of the dry sediment samples (Hedges \& Stern 1984). First, inorganic carbon was removed. Since all the sampling sites are on limestone bedrock, violent effervescence was prevented by adding a small amount of distilled water $(\sim 20 \mu \mathrm{l})$ before acidification; $1 \mathrm{M} \mathrm{HCl}$ acid was then added until effervescence ceased, indicating complete removal of carbonates. Finally, OC concentration was measured using a $\mathrm{CHN}$ elemental analyser (Carlo Erba, EA 1008) at a combustion temperature of $1020^{\circ} \mathrm{C}$. For TN determination, the samples were analysed using an elemental analyser without any acid 
pre-treatment. Blank samples and standards with known elemental composition were used for quality assurance. The precision of the method, expressed in terms of standard deviations, was from 3 to $5 \%$.

\section{RESULTS}

\section{ETS activity}

In Lake Kriško Sup., Lake Ledvica and Lake Planina, a subsurface maximum in the ETS activity distribution was observed (Figs. 1 to 3). At the sediment surfaces, ETS activity was low, amounting to 165, 75 and $275 \mu \mathrm{O}_{2} \mathrm{~g}^{-1} \mathrm{DW} \mathrm{h}^{-1}$, respectively. It then increased steeply in the upper 3 to $5 \mathrm{~cm}$ of the sediments, reaching a maximum value of $385 \mu \mathrm{O}_{2} \mathrm{~g}^{-1} \mathrm{DW} \mathrm{h} \mathrm{h}^{-1}$ in Lake Kriško Sup., $280 \mu \mathrm{l} \mathrm{O}_{2} \mathrm{~g}^{-1} \mathrm{DW} \mathrm{h}^{-1}$ in Lake Ledvica and $320 \mu \mathrm{O}_{2} \mathrm{~g}^{-1} \mathrm{DW} \mathrm{h}^{-1}$ in Lake Planina. In all deeper sediments, a rapid decrease of ETS activity was observed with increasing depth of the sediments. In the last measured slice, ETS activity dropped below $10 \mu \mathrm{O} \mathrm{O}_{2} \mathrm{~g}^{-1} \mathrm{DW} \mathrm{h} \mathrm{h}^{-1}$ in Lake Ledvica, to $50 \mu \mathrm{O}_{2} \mathrm{~g}^{-1}$ DW h $\mathrm{h}^{-1}$ in Lake Planina and to $100 \mathrm{\mu l} \mathrm{O}_{2} \mathrm{~g}^{-1} \mathrm{DW} \mathrm{h}^{-1}$ in Lake Kriško Sup. Some fluctuations in ETS activity were observed in all sediments. In Lake Kriško Sup., variations were not significant (Fig. 1). In Lake Ledvica, however, a significant local peak in ETS activity was noted at a depth of $18 \mathrm{~cm}$, reaching $95 \mu \mathrm{O} \mathrm{O}_{2} \mathrm{~g}^{-1}$ DW $\mathrm{h}^{-1}$ (Fig. 2). ETS activity in Lake Planina sedi-

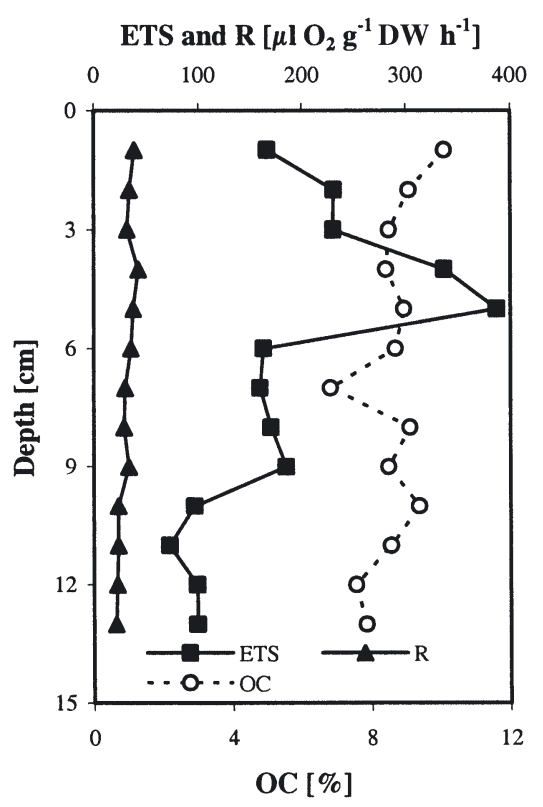

Fig. 1. Vertical profiles of electron transport system (ETS) activity, oxygen consumption rate $(R)$ and organic carbon (OC) concentration in Lake Kriško Sup. sediments. DW: dry weight

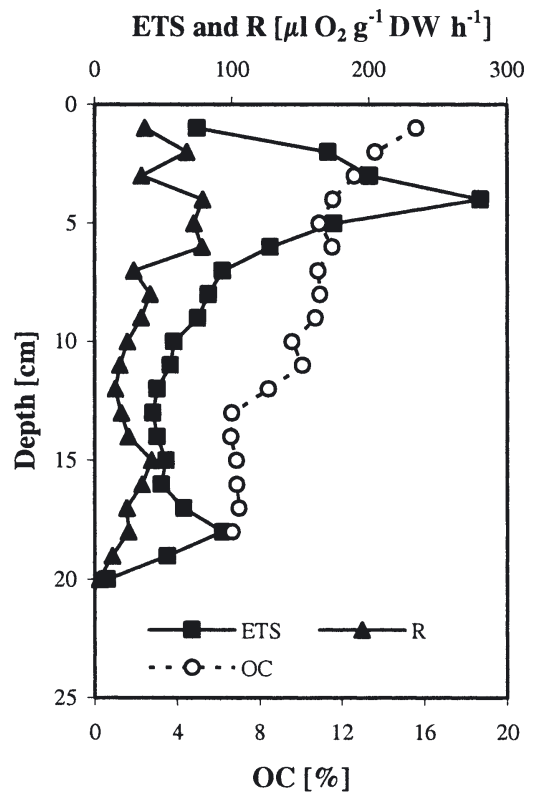

Fig. 2. Vertical profiles of electron transport system (ETS) activity, oxygen consumption rate $(R)$ and organic carbon (OC) concentration in Lake Ledvica sediments. DW: dry weight

ments also varied significantly in deeper sediments, resulting in local maxima at depths of 9 and $16 \mathrm{~cm}$ (Fig. 3).

In contrast, different ETS activity profile was observed in the urban Lake Bled (Fig. 4). The highest ETS activity was observed in the surface sediment. It amounted to $310 \mu \mathrm{O}_{2} \mathrm{~g}^{-1} \mathrm{DW} \mathrm{h} \mathrm{h}^{-1}$ and decreased rapidly in the deeper sediments. At a depth of $20 \mathrm{~cm}$, a value of $10 \mu \mathrm{O}_{2} \mathrm{~g}^{-1} \mathrm{DW} \mathrm{h} \mathrm{h}^{-1}$ was observed.

\section{Oxygen consumption rate}

$R$ in Lake Kriško Sup. decreased with increasing depth (Fig. 1), dropping from $40 \mu \mathrm{O}_{2} \mathrm{~g}^{-1} \mathrm{DW} \mathrm{h}^{-1}$ at the sediment surface to $20 \mu \mathrm{O}_{2} \mathrm{~g}^{-1} \mathrm{DW} \mathrm{h}^{-1}$ at a depth of $13 \mathrm{~cm}$. Slight, mostly non-significant variations in $R$ were observed down the core. Similarly, $R$ of $35 \mu \mathrm{O}_{2} \mathrm{~g}^{-1} \mathrm{DW} \mathrm{h} \mathrm{h}^{-1}$ was observed in the Lake Ledvica surface sediment layer (Fig. 2). However, a steep increase in $R$ was noted in the subsurface sediments, at a depth of around $5 \mathrm{~cm}$, reaching $80 \mu \mathrm{O}_{2}$ $\mathrm{g}^{-1} \mathrm{DW} \mathrm{h}^{-1}$. It then decreased dramatically. At a depth of $15 \mathrm{~cm}$, a local peak of $40 \mu \mathrm{O}_{2} \mathrm{~g}^{-1} \mathrm{DW} \mathrm{h}^{-1}$ was observed. Strong fluctuations of $R$ with depth were observed in Lake Planina (Fig. 3). $R$ was $90 \mu \mathrm{l}$ $\mathrm{O}_{2} \mathrm{~g}^{-1} \mathrm{DW} \mathrm{h}^{-1}$ in the surface sediment but varied from 30 to $95 \mu \mathrm{O} \mathrm{O}_{2} \mathrm{~g}^{-1} \mathrm{DW} \mathrm{h}^{-1}$ in the upper $8 \mathrm{~cm}$ of sediments. In the deeper sediments it dropped below $35 \mu \mathrm{O}_{2} \mathrm{~g}^{-1} \mathrm{DW} \mathrm{h}^{-1}$. 


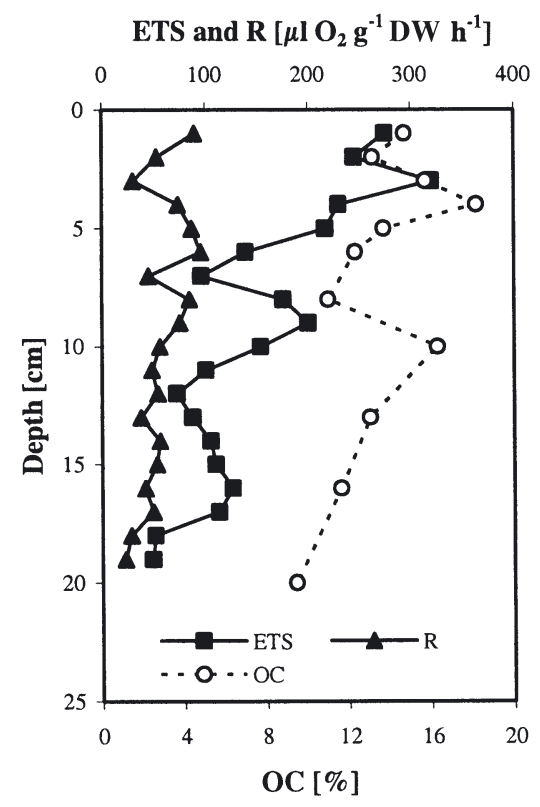

Fig. 3. Vertical profiles of electron transport system (ETS) activity, oxygen consumption rate $(R)$ and organic carbon (OC) concentration in Lake Planina sediments. DW: dry weight

In contrast, $R$ was $45 \mu \mathrm{O} \mathrm{O}_{2} \mathrm{~g}^{-1} \mathrm{DW} \mathrm{h}^{-1}$ in the surface sediment layer of Lake Bled (Fig. 4). It decreased steeply down the core to around $5 \mu \mathrm{O}_{2} \mathrm{~g}^{-1} \mathrm{DW} \mathrm{h}^{-1}$ in the deeper sediments.

\section{Organic carbon concentration}

OC concentration in Lake Kriško Sup. ranged from 10 to $8 \%$ (Fig. 1). Higher concentrations were observed in the upper sediments and lower in the deeper sediments. OC concentration varied only slightly down the core. In Lake Ledvica, the surface sediment OC concentration was $16 \%$ (Fig. 2). It decreased rapidly with depth to $7 \%$ at a depth of $18 \mathrm{~cm}$. A substantial drop was observed at depths between 11 and $13 \mathrm{~cm}$, where OC concentration decreased by $3.5 \%$. OC concentration in Lake Planina was $15 \%$ in the surface sediment layer (Fig. 3). A subsurface maximum was observed at a depth of $4 \mathrm{~cm}$, with $\mathrm{OC}$ concentration increasing to $18 \%$. A local peak was also observed at a depth of $10 \mathrm{~cm}$, where OC concentration was $16 \%$. In the deeper sediments, it decreased considerably, dropping back to $9 \%$ at a depth of $20 \mathrm{~cm}$.

OC concentration in Lake Bled was much lower (Fig. 4). It was $5 \%$ at the sediment surface and then decreased gradually with depth. A subsurface peak value was observed at a depth of $13 \mathrm{~cm}$, where OC concentration reached nearly $5 \%$. However, it averaged around $3 \%$ in the deeper sediments.

\section{$\mathrm{C} / \mathrm{N}$ ratio and alkanes}

$\mathrm{C} / \mathrm{N}$ ratios ranged from 7.5 to 12.3 and increased with increasing depth in all sediments (Fig. 5). The lowest surface sediment $\mathrm{C} / \mathrm{N}$ ratio was 8.2, observed in Lake Kriško Sup. Higher surface sediment $\mathrm{C} / \mathrm{N}$ ratios were observed in Lake Bled and Lake Ledvica, amounting to 8.9 and 9.2, respectively, but the highest value was in Lake Planina at 10.5. Some fluctuations in the vertical

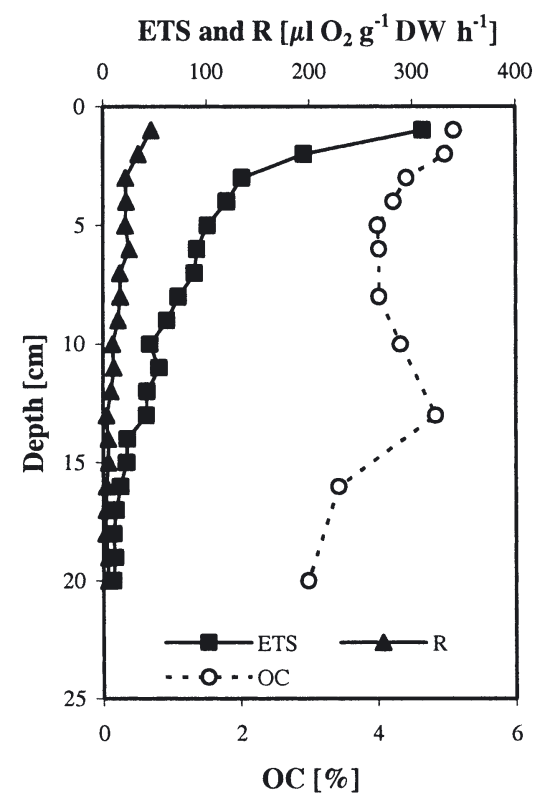

Fig. 4. Vertical profiles of electron transport system (ETS) activity, oxygen consumption rate $(R)$ and organic carbon (OC) concentration in Lake Bled sediments. DW: dry weight

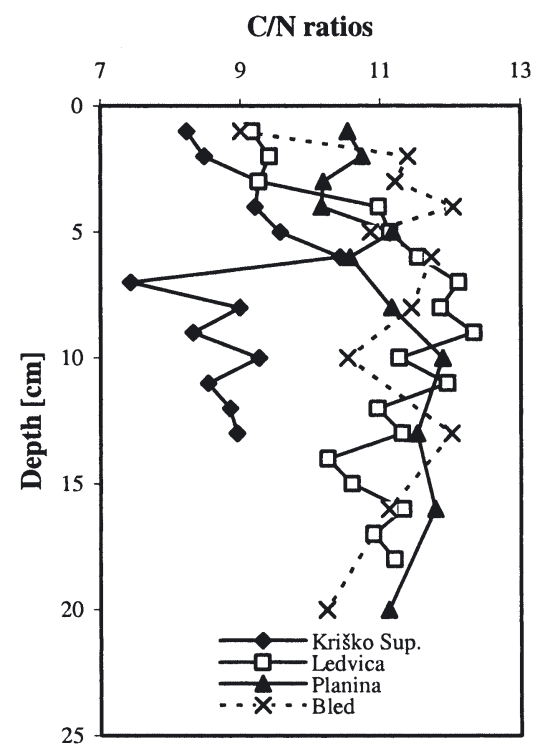

Fig. 5. Vertical profiles of $\mathrm{C} / \mathrm{N}$ ratios in sediments 


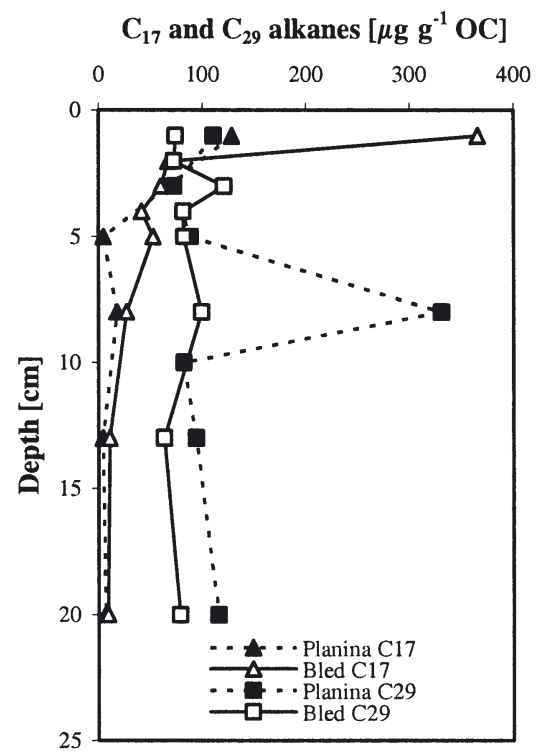

Fig. 6. Vertical profiles of autochthonous $\left(n-\mathrm{C}_{17}\right)$ and terrestrial alkanes $\left(n-C_{29}\right)$ in Lake Planina and Lake Bled sediments (data from Muri 2003)

profiles of $\mathrm{C} / \mathrm{N}$ ratios were observed, mostly associated with increased inputs of terrestrial materials.

In Lake Planina and Lake Bled, vertical profiles of $n-\mathrm{C}_{17}$ and $n-\mathrm{C}_{29}$ alkanes were also determined (Fig. 6). The concentration of $n-C_{17}$ was $128 \mu \mathrm{g} \mathrm{g}^{-1} \mathrm{OC}$ in the former and $365 \mathrm{\mu g} \mathrm{g}^{-1} \mathrm{OC}$ in the latter, and decreased rapidly with increasing depth in both sediments. In contrast, the vertical profile of $n-C_{29}$ was uniform in Lake Bled, averaging $84 \mu \mathrm{g} \mathrm{g}^{-1} \mathrm{OC}$. In Lake Planina, $n-\mathrm{C}_{29}$ concentrations were around $94 \mu^{-1} \mathrm{~g}^{-1}$ OC. However, a significant, 3 -fold increase of $n-\mathrm{C}_{29}$ concentration was observed at a depth of $9 \mathrm{~cm}$, indicating a substantial contribution of terrestrial OM to Lake Planina sediments.

\section{Correlations}

Correlation coefficients between ETS activity and $R$, ETS activity and OC concentration, and $R$ and OC concentration were also calculated (Table 2). Significant correlations were found between ETS activity and $R$ in all sediments, with values of $\mathrm{r}$ ranging from 0.53 to 0.97. There was no significant correlation between ETS activity and OC concentration in Lake Kriško Sup. sediments. In the sediments from the other lakes, significant correlations were found between the 2 parameters, with r ranging from 0.54 to 0.73 . The weakest, though significant, correlation was found between $R$ and OC concentration: 0.49 in Lake Ledvica and 0.63 in Lake Bled sediments. However, there was no significant correlation between the 2 parameters in Lake Kriško Sup. or Lake Planina sediments.

\section{DISCUSSION}

\section{Surface-sediment ETS activity and oxygen consumption rate $(R)$}

The highest surface-sediment ETS activities were observed in the eutrophic lakes, i.e. Lake Bled and Lake Planina. Higher temperatures of the water column were noted in the former lake. Additionally, autochthonous OM was predominant in Lake Bled due to intensive primary production (Čermelj et al. 1996). Autochthonous lipids therefore comprised around 55\% of the total lipids (Table 1). Autochthonous predominance of OM was also reflected in lower $\mathrm{C} / \mathrm{N}$ ratios (Fig. 5) in Lake Bled. In Lake Planina, C/N ratios were higher, pointing to a higher proportion of terrestrial OM. This was confirmed by lipid analyses of the sediment. It was found that lipids of terrestrial origin comprised approximately $66 \%$ of the total lipids in the surface sediment. Autochthonous OM of planktonic and bacterial origin, which has $\mathrm{C} / \mathrm{N}$ ratios from 5 to 8 , is more easily and rapidly decomposed than terrestrial OM (Meyers 1997). In accordance with higher lake water temperature and higher content of autochthonous, more labile OM, microbial respiratory activity in Lake Bled was higher than in Lake Planina, and consequently higher ETS activity was observed in the former lake. In the study of Relexans (1996), higher ETS activities were also observed in sediments with a higher content of labile OM.

Much lower surface sediment ETS activities were observed in the oligotrophic lakes. Several other studies have also shown that ETS activity was remarkably higher in eutrophic lakes than in less productive lakes (e.g. G.-Tóth 1992, G.-Tóth et al. 1994). In Lake Ledvica, ETS activity was roughly 4 -fold lower, while in Lake Kriško Sup. it was approximately 2-fold lower than in Lake Planina, although they are all mountain lakes. Lake Ledvica is higher than Lake Planina, so the lake water temperature is lower, resulting in lower microbial respiratory activity (den Heyer \& Kalff 1998).

Table 2. Correlation coefficients (r) between electron transport system (ETS) activity and oxygen consumption rate $(R)$, ETS activity and organic carbon (OC) concentration, and $R$ and $\mathrm{OC}$ concentration in the sediments. ${ }^{\mathrm{ns}}$ : not significant $(\mathrm{p}>0.05)$

\begin{tabular}{|lccl|}
\hline Lake & \multicolumn{3}{r|}{} \\
& ETS/R & ETS/OC & R/OC \\
\hline Kriško Sup. & 0.83 & $0.17^{\text {ns }}$ & $0.36^{\text {ns }}$ \\
Ledvica & 0.79 & 0.54 & 0.49 \\
Planina & 0.53 & 0.60 & $0.11^{\text {ns }}$ \\
Bled & 0.97 & 0.73 & 0.63 \\
\hline
\end{tabular}


Lake Kriško Sup. has the lowest water temperatures, since the lake is situated at a high altitude and is covered with ice for up to 9 mo in the year (Brancelj 2002). However, the ETS activity observed in Lake Kriško Sup. was higher than in Lake Ledvica, most probably due to the different composition of OM. The surface sediment $\mathrm{C} / \mathrm{N}$ ratio in Lake Kriško Sup. was lower than in Lake Ledvica (Fig. 5). This indicates that OM in Lake Kriško Sup. is mostly of autochthonous origin, as also demonstrated by Vreča \& Muri (2002), while in Lake Ledvica a relatively higher proportion of $\mathrm{OM}$ is comprised of more refractory terrestrial OM.

Similar patterns were observed for $R$. Nevertheless, all the $R$ values were much lower than the ETS activities, since part of the measured ETS activity in sediments derived from inactive ETS fractions from dead organisms in plankton and benthic deposits (G.-Tóth et al. 1994). Detrital material contributes to ETS activity measurements but not to $R$. It was demonstrated that ETS fractions of planktonic and other organisms remain active for days or weeks after their death (G.-Tóth 1992, G.-Tóth et al. 1994). $R$, induced under laboratory conditions, was again higher in the eutrophic than in the oligotrophic lakes, but the differences were smaller. The surface sediment values of $R$ in Lake Kriško Sup. and in Lake Ledvica were very similar, with slightly higher $R$ observed in the former, as in the case of ETS activity. In contrast to the ETS activity distribution, $R$ in Lake Planina was higher than in Lake Bled. This could be explained by the relatively long incubation period (about $70 \mathrm{~h}$ ). OM in Lake Bled is completely decomposed, while in Lake Planina it is partly buried (cf. depth profiles of ETS activity and $R$ in Figs. 4 \& 3, respectively). During the laboratory incubation period, with more favourable conditions (higher temperature and high oxygen saturation level), more refractory forms of Lake Planina OM can be completely decomposed, since the number of bacteria and other benthic animals can increase through reproduction and/or activation of latent forms.

\section{Depth profiles of ETS activity and oxygen consumption rate}

ETS activity and $R$ increased with increasing depth in the upper sediments of all the mountain lakes (Figs. 1 to 3). The highest values were observed below the sediment surface at depths of 3 to $5 \mathrm{~cm}$. There are several possible reasons for this specific distribution. Microbial respiratory activity in the cold waters of mountain lakes is low, causing slow degradation of $\mathrm{OM}$. Autochthonous, as well as terrestrial, OM is present in all these lakes and is available for feeding to organisms. Autochthonous OM is normally effectively degraded already in the water column and surface sediments (Vosjan \& Olanczuk-Neyman 1977, Relexans 1996). In contrast, terrestrial OM is more refractory. We presume that a longer period is needed to degrade terrestrial components to the forms which can be further decomposed by bacteria, and that this is then reflected in increased levels of ETS activity and $R$ in the upper sediment layers. However, subsurface peaks could also indicate the presence of anaerobic microorganisms, since these peaks were found in that part of the sediment where oxygen depletion had occurred. Similar distributions were also noted in some other studies (Christensen 1983, Relexans 1996). Most probably, ETS activity and $R$ distribution were affected by both factors. ETS activity and $R$ eventually dropped below a depth of approximately $5 \mathrm{~cm}$. Hence, much lower ETS activity and $R$ were observed in the bottom sediment layers of the cores, probably indicating that mineralisation of OM had ceased. In general, decreasing ETS activity and $R$ with increasing depth depends both on the stabilisation of sediment and the termination of aerobic metabolism (Broberg 1985, SongsterAlpin \& Klotz 1995). However, remarkable increases in ETS activity and $R$ were observed in Lake Ledvica sediments at depths from 15 to $17 \mathrm{~cm}$ (Fig. 2). There was a strong earthquake in this region in 1895 (Ribarič 1982). At a depth of $11 \mathrm{~cm}$, corresponding to around 1900 (Brancelj et al. 2002), the $\mathrm{C} / \mathrm{N}$ ratio increased to 12 . Increased quantities of terrestrial $\mathrm{OM}$ could have entered the lake at that time due to landslides and changes in the lake's catchment. Since conditions are unfavourable for OM degradation in this mountain lake, this fresh terrestrial OM would need longer to totally decompose. We therefore suspect that this fresh terrestrial OM was only partly degraded, while the remainder, although still potentially available for degradation, was buried in the sediments where microbial respiratory activity is minimal. However, under laboratory conditions with higher temperature and high oxygen saturation level, this buried OM could decompose completely. Thus, the increased levels of ETS activity and $R$ reflected OM that was still degradable, although buried in the sediments.

In Lake Planina sediment, ETS activity and $R$ varied considerably down the core (Fig. 3), probably reflecting the mixed composition of OM. We observed 3 peak values of ETS activity in the deeper sediments, at depths of 3,9 and $16 \mathrm{~cm}$. The upper peak indicated decomposition of contemporary OM. The 2 deeper peak values corresponded to inputs of substantial amounts of fresh OM, as also shown by the peaks of $\mathrm{OC}$ at depths of 4 and $10 \mathrm{~cm}$ (Fig. 3). In these sediment layers, the lipid distribution had changed, containing a higher proportion of terrestrial lipids (Fig. 6). On the other hand, C/N ratios also increased (Fig. 5). Local 
peak values in ETS activity were then observed in the sediment layers, which lie some 3 to $5 \mathrm{~cm}$ below the layer in which the terrestrial OM input occurred. In the case of the $R$ profile, the subsurface peak values were harder to distinguish, but were also consistent with degradation of contemporary OM and input of fresh terrestrial OM.

High correlations were generally found between ETS activity, $R$ and OC concentration in all sediments (Table 2). Lake Kriško Sup. was an exception, since the correlations between ETS activity and OC concentration, and between $R$ and OC concentration were not significant. This can be explained by the limited set of sediment samples obtained from this lake: as the lake has a gravelled bottom only, a short sediment core could be collected and only 13 samples were analysed.

Most mineralisation of $\mathrm{OM}$ in the mountain lakes took place in the upper 3 to $5 \mathrm{~cm}$ of the sediments. These sediments had accumulated over the last 10 to $35 \mathrm{yr}$, since different sedimentation rates were observed in these lakes (for sedimentation rates see Brancelj et al. 2002, Muri et al. 2002, 2003). The shortest period of around $10 \mathrm{yr}$ was in the eutrophic Lake Planina, which has the warmest water. A similar time span of approximately $12 \mathrm{yr}$ was found for Lake Kriško Sup. OM is mostly autochthonous, and thus easy to degrade. A much longer period of around $35 \mathrm{yr}$ for OM degradation was observed in Lake Ledvica. There the lake water is cold and the OM is more refractory. Thus, both lake water temperature as well as OM lability appear to have a strong impact on ETS activity and $R$ in the sediments.

In contrast, the ETS activity and $R$ profiles in Lake Bled showed no variation at all, even with the varying OC content (Fig. 4). It can be concluded that microbial respiratory activity here is much higher than in the other 3 mountain lakes due to higher water temperatures and longer sinking times. Hence, autochthonous as well as terrestrial components of $\mathrm{OM}$ are already effectively degraded in the water column and in the surface sediments.

\section{Conclusions}

Higher ETS activities and $R$ were observed in the surface sediments of the eutrophic lakes than in the oligotrophic lakes. When comparing the eutrophic lakes Lake Bled and Lake Planina, higher microbial respiratory activity was observed in the warmer and more productive Lake Bled. Comparing the oligotrophic lakes, higher ETS activity and $R$ was observed in Lake Kriško Sup. Although the latter is higher than Lake Ledvica, with lower lake water temperatures, it has a relatively larger proportion of labile autochtho- nous OM. $R$, induced under laboratory conditions, was much lower than the ETS activities, since part of the measured ETS activity in sediments was derived from inactive ETS fractions from dead organisms in plankton and benthic deposits.

In respect to depth profiles, ETS activity and $R$ decreased with increasing depth in all lakes. In the mountain lakes, subsurface peak values were observed, probably indicating a slower degradation of OM (in particular more refractory terrestrial components) and the presence of anaerobic microorganisms. Increased levels of ETS activity and $R$ were observed in the sediment layers around 3 to $5 \mathrm{~cm}$ below those where the input of fresh terrestrial OM had occurred. This indicates that part of the potentially degraded OM remained buried in these sediments. In Lake Bled, no subsurface peak values were observed. The highest microbial respiratory activity was observed in this lake, reflecting its high water temperatures and high content of labile autochthonous OM. Consequently, OM was effectively decomposed in the water column and surface sediments. In general, a good correlation between ETS activity, $R$ and OC concentration was observed in all sediments examined.

Acknowledgements. We thank A. Brancelj and J. Faganeli for comments and suggestions on an earlier version of the manuscript. We also wish to acknowledge the helpful comments of 2 anonymous reviewers. The study was financially supported by the Slovenian Ministry of Education, Science and Sport (project SLO-Alpe).

\section{LITERATURE CITED}

Brancelj A (2002) High-mountain lakes in the Eastern part of the Julian Alps. ZRC Publishing, Ljubljana

Brancelj A, Šiško M, Muri G, Appleby P and 6 others (2002) Lake Jezero v Ledvici (NW Slovenia) — changes in sediment records over the last two centuries. J Paleolimnol 28: $47-58$

Broberg A (1985) A modified method for studies of electron transport system activity in freshwater sediments. Hydrobiologia 120:181-187

Čermelj B, Faganeli J, Ogorelec B, Dolenec T, Pezdič J, Smodiš B (1996) The origin and recycling of sedimented biogenic debris in a subalpine eutrophic lake (Lake Bled, Slovenia). Biogeochemistry 32:69-92

Christensen JP (1983) Electron transport system activity and oxygen consumption in marine sediments. Deep-Sea Res 30:183-194

del Giorgio PA (1992) The relationship between ETS (electron transport system) activity and oxygen consumption in lake plankton: a cross-system calibration. J Plankton Res 14: 1723-1741

den Heyer C, Kalff J (1998) Organic matter mineralization rates in sediments: a within- and among-lake study. Limnol Oceanogr 43:695-705

G.-Tóth L (1992) Respiratory electron transport system activity (ETS) - activity of the plankton and sediment in Lake Balaton (Hungary). Hydrobiologia 243/244:157-166 
G.-Tóth L (1999) Aktivität des Electronentransportsystems. In: von Tümpling $\mathrm{W}$, Friedrich $\mathrm{G}$ (eds) Biologische Gewässeruntersuchung: Methoden der Biologischen Wasseruntersuchung 2. Gustav Fischer Verlag, Jena, p 465-473

G.-Tóth L, Langó Z, Padisák J, Varga E (1994) Terminal electron transport system (ETS) - activity in the sediment of Lake Balaton, Hungary. Hydrobiologia 281:129-139

G.-Tóth L, Carrillo P, Cruz-Pizarro L (1995) Respiratory electron transport system (ETS) - activity of the plankton and biofilm in the high-mountain lake La Caldera (Sierra Nevada, Spain). Arch Hydrobiol 135:65-78

Hedges JI, Stern JH (1984) Carbon and nitrogen determination of carbonate-containing solids. Limnol Oceanogr 29: 657-663

Kenner RA, Ahmed SI (1975) Correlation between oxygen utilization and electron transport activity in marine phytoplankton. Mar Biol 33:129-133

Lampert W (1984) The measurement of respiration. In: Downing JA, Rigler FH (eds) A manual on methods for the assessment of secondary productivity in fresh water. Blackwell Scientific Publications, Oxford, p 413-468

Meyers PA (1997) Organic geochemical proxies of paleoceanographic, paleo-limnologic and paleoclimatic processes. Org Geochem 27:213-250

Muri G (2003) Composition and origin of organic matter in oxic and anoxic alpine lakes. PhD thesis, University of Ljubljana

Muri G, Brancelj A (2003) Seasonal water chemistry variations in three Slovenian mountain lakes. Acta Chim Slov 50:137-147

Muri G, Čermelj B, Faganeli J, Brancelj A (2002) Black carbon in Slovenian alpine lacustrine sediments. Chemosphere 46:1225-1234

Muri G, Wakeham SG, Faganeli J (2003) Polycyclic aromatic hydrocarbons and black carbon in sediments of a remote alpine lake (Lake Planina, northwest Slovenia). Environ Toxicol Chem 22:1009-1016

Packard TT (1985) Measurement of electron transport activity

Editorial responsibility: Kevin Carman,

Baton Rouge, Louisiana, USA of microplankton. In: Jannasch H, Williams PJLeB (eds) Advances in aquatic microbiology. Academic Press, London, p 207-261

Packard TT, Williams PJ LeB (1981) Rates of respiratory oxygen consumption and electron transport in surface seawater from the northwest Atlantic. Oceanol Acta 4:351-358

Relexans JC (1996) Measurement of the respiratory electron transport system (ETS) activity in marine sediments: stateof-the-art and interpretation. I. Methodology and review of literature data. Mar Ecol Prog Ser 136:277-287

Ribarič V (1982) Seismicity of Slovenia. Seismological Institute of Slovenia, Ljubljana (in Slovenian)

Simčič T (2000) Seasonal dynamics of enzymatic activity of respiratory chain and respiration rate in genus Daphnia (Cladocera) in Lake Bled. PhD thesis, University of Ljubljana (in Slovenian, with English abstract)

Simčič T, Brancelj A (2002) Intensity of mineralization processes in mountain lakes in NW Slovenia. Aquat Ecol 36: 345-354

Songster-Alpin MS, Klotz RL (1995) A comparison of electron transport system activity in stream and beaver pond sediments. Can J Fish Aquat Sci 52:1318-1326

Suess E (1980) Particulate organic carbon flux in the oceansurface productivity and oxygen utilization. Nature 288: $260-263$

Thies H, Nickus U, Arnold C, Schnegg R, Wille A, Psenner R (1999) Biogeochemistry of a high mountain lake in the Austrian Alps. Verh Int Ver Limnol 27:517-520

Trevors JT (1984) The measurement of electron transport system (ETS) activity in freshwater sediment. Water Res 18: 581-584

Vosjan JH, Olanczuk-Neyman KM (1977) Vertical distribution of mineralization processes in a tidal sediment. Neth J Sea Res 11:14-23

Vreča P, Muri G (2002) Stable isotopic composition of sedimentary organic carbon and nitrogen as indicator of trophic state changes in high-mountain lakes in the Julian Alps. Geologija 45:607-612 (in Slovenian, with English abstract)

Submitted: June 7, 2003; Accepted: November 26, 2003 Proofs received from author(s): February 24, 2004 